\title{
A Case Report about Diabetes Mellitus and COVID-19 Outbreak
}

\author{
Diabetes Mellitus ve COVID-19 Salgını Hakkında Bir Olgu Sunumu
}

\author{
Hafize KIZILKAYA ${ }^{\mathbf{1}}$ \\ (1) 0000-0002-4878-9958

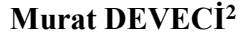 \\ (D) 0000-0001-8292-4343
}

\begin{abstract}
The coronavirus disease 2019 (COVID-19) pandemic has almost collapsed most of the health systems of communities around the world. The rapid increase in the number of cases has brought this virus to the top of the agenda, and many issues such as the mode of transmission of the virus, how long it remains alive, how it should be protected have been the most researched topics in the last year. It is observed that mortality is high especially in patients with chronic diseases and elderly patients. In also diabetes mellitus, one of the chronic diseases, the risk of morbidity and mortality is high due to COVID-19. Our case report states that there are impairments in blood glucose regulation in the follow-up of patients with diabetes mellitus hospitalized due to COVID-19 infection and that they should be dealt with, and the course of COVID-19 infection with poor prognosis.

Keywords: Diabetes mellitus; coronavirus; pathogenesis; SARS-CoV-2.
\end{abstract}

ÖZ

Koronavirüs hastalığı 2019 (coronavirüs disease 2019, COVID-19) salgını, dünyanın dört bir yanında, toplumlarda sağlık sistemini nerdeyse çökertmiştir. Vaka sayısının çok hızlı bir şekilde artışı bu virüsü gündemin en üstüne taşımış ve virüsün bulaş şekli, ne kadar süre canlı kaldığı, nasıl korunulması gerektiği gibi birçok konu son bir yılın en çok araştırılan konuları olmuştur. Özellikle kronik hastalıkları olan ve ileri yaştaki hastalarda mortalitenin yüksek olduğu gözlenmektedir. Kronik hastalıklardan biri olan diyabetes mellitusta da COVID-19 nedeni ile morbidite ve mortalite riski yüksektir. Olgu sunumumuz, COVID-19 enfeksiyonu nedeni ile hastaneye yatırılan diyabetes mellitus tanılı hastaların takiplerinde kan şekeri regülasyonunda bozulmalar olduğunu ve bunlarla baş edilmesi gerektiğini ve COVID-19 enfeksiyonunun kötü prognozla gidişatını göstermektedir.

Anahtar kelimeler: Diabetes mellitus; koronavirüs; patogenez; SARS-CoV-2.

\section{INTRODUCTION}

The coronavirus disease 2019 (COVID-19) case first appeared in Wuhan, China at the end of 2019 and was declared as a global pandemic in March 2020 after a very short time (1). Being an enveloped RNA virus, coronavirus gets its name from using the surface protein in the form of a crown (corona) when attaching to the host cell. Coronaviruses can infect animals and humans, causing respiratory, gastrointestinal, hepatic and neurological diseases.
Received / Geliş Tarihi : 27.08.2020 Accepted / Kabul Tarihi : 09.11.2020 Available Online /

Çevrimiçi Yayın Tarihi : 25.11.2020 
Dry cough, high fever, and respiratory distress are among the most common symptoms of COVID-19 infection. These findings are generally mild. However, sometimes the disease can lead to multiple organ failure and severe pneumonia. The data show that the mortality rate is $1-2 \%$ (2). Although most patients progress asymptomatically, the condition may be more severe in the elderly and those with comorbid diseases. Hospitalization rates and the need for intensive care are also high in these people.

It is stated that people with diabetes are more likely to get COVID-19 than the general population, but we do not have enough data yet. The problem faced by people with diabetes is primarily a problem of worse outcomes, not chances of getting the virus. People with diabetes have much higher rates of serious complications and deaths than those without diabetes, and in general, the more health conditions (e.g. diabetes and heart disease) a person has, the more likely they are to suffer serious complications from COVID-19. Advanced age, obesity, and smoking are among the factors that increase the risk of complications (3).

In this case report, we aimed to discuss the problems experienced by a diabetic patient with COVID-19 infection during treatment and the factors that negatively affect her treatment.

\section{CASE REPORT}

A 76-year-old female patient with a previously known diagnosis of diabetes mellitus, hypertension and coronary artery disease visited our hospital. Her medications were as follows: gliclazide $30 \mathrm{mg}$, two tablets daily, losartan potassium/hydrochlorothiazide $50 / 12.5 \mathrm{mg}$, one tablet daily, metoprolol $50 \mathrm{mg}$, one tablet daily. She was using an oral antidiabetic for diabetes treatment. The patient presented with complaints of fever, back pain, and shortness of breath that started 1 day before admission. On her physical examination upon arrival, her general condition was moderate. She had mild tachypnea, a respiratory rate of 24 , a temperature of $37.9{ }^{\circ} \mathrm{C}$, blood pressure of 155/95 $\mathrm{mmHg}$, and oxygen saturation (at room air) of $95 \%$. On examination, her liver function tests and kidney function tests were normal. Her C-reactive protein (CRP) level was $11 \mathrm{mg} / \mathrm{L}$, and her white blood cell count was $8600 \mathrm{~mm}^{3}$ (neutrophil 95\%, lymphocyte 2\%). Her hemoglobin, ferritin and procalcitonin levels were 12.3 $\mathrm{g} / \mathrm{dL}, 348 \mathrm{ng} / \mathrm{mL}$ and $0.29 \mathrm{ng} / \mathrm{mL}$, respectively. Her platelet count was $156000 \mathrm{U} / \mathrm{L}$. Her lactate dehydrogenase and D-dimer levels were $616 \mathrm{U} / \mathrm{L}$ and $670 \mu \mathrm{g} / \mathrm{mL}$, respectively. Computed tomography (CT) was requested because of the complaints of fever, shortness of breath and comorbid disease. Peripheral multiple infiltration areas extending from apex to basal in a patchy pattern in bilateral lung parenchyma seen on thoracic CT (Figures 1 and 2) were found to be compatible with COVID-19 infection, and when the patient's history was deepened, there was a history of contact with another patient diagnosed with COVID-19. For this reason, the COVID-19 polymerase chain reaction (PCR) test was taken after being hospitalized and the test result was positive. In addition to her drugs, favipiravir $200 \mathrm{mg}$ one tablet twice a day, heparin $0.6 \mathrm{mg}$, once a day SC, hydroxychloroquine 200 $\mathrm{mg}$, one tablet twice a day, methylprednisolone $40 \mathrm{mg}$ ampoule once daily, bronchodilator and symptomatic treatment were started. In the blood glucose monitoring, the regulated blood glucose values increased to 200-300 on the $3^{\text {rd }}$ day of her hospitalization. For the treatment of the patient, it was planned to keep blood glucose in the range of 120-200 by adding crystallized insulin according to the blood glucose before meals. On the $5^{\text {th }}$ day of her admission, the patient's respiratory distress increased and his oxygen saturation regressed to 90 . She was followed up in the intensive care unit. During the follow-up in the intensive care unit, the insulin doses were continuously increased as the blood glucose levels remained at 300. The patient was not intubated. She was treated in intensive care for 3 days, and when vital signs stabilized she was followed up in the service again. The patient's treatment continued in the service for 7 days and was discharged with basal-bolus insulin therapy with recommendations.

\section{DISCUSSION}

The frequency of COVID-19 in individuals with comorbid disease also varies in different studies and country-based data. It has been reported that the diabetes prevalence in COVID-19 patients in different regions of China is at high values ranging from $7.4-20 \%$ (4). The prevalence of diabetes in COVID-19 patients hospitalized in Italy was found to be $8.9 \%$, and this rate is above the prevalence of advanced age diabetes (5).

In different studies, COVID-19 patients with diabetes were found to be more frequently associated with serious or critical illness, ranging from $14 \%$ to $32 \%$ (6). Initial data reported that infection with COVID-19 and the development of severe pneumonia were higher in diabetics compared to those without diabetes, thus mortality rates

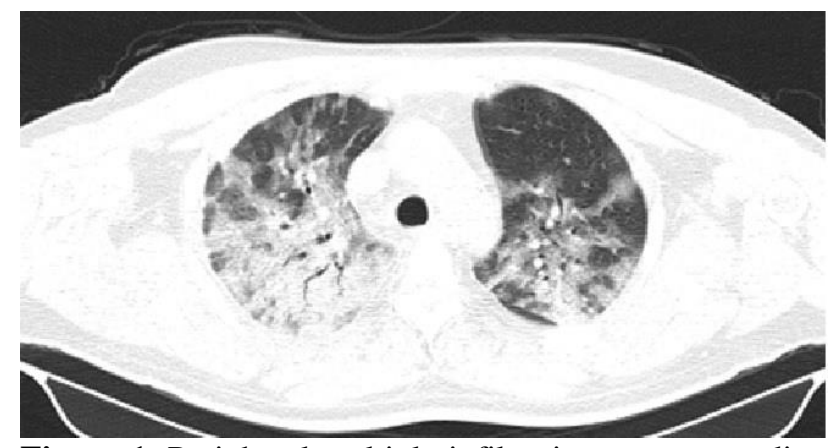

Figure 1. Peripheral multiple infiltration areas extending from apex to basal patchy in bilateral lung parenchyma seen on thorax computed tomography

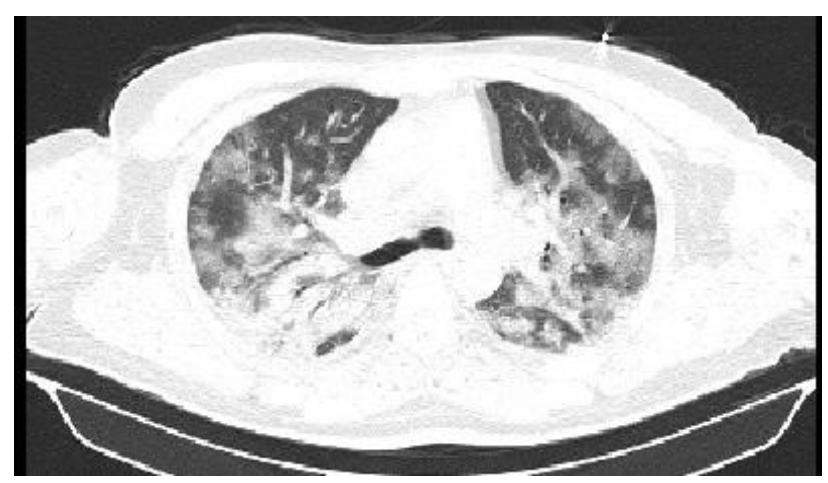

Figure 2. Peripheral multiple infiltration areas extending from the apex to basal in a patchy pattern in the bilateral lung parenchyma on thorax computed tomography 
were also higher (7). While the need for intensive care is around $30 \%$ for those without chronic diseases, this rate can reach up to $70 \%$ for diabetic individuals. There is a significant correlation between COVID-19 severity and diabetes. It is also reported that mortality in diabetic individuals with COVID-19 varies between $22-31 \%$ (8). It is said that mortality in people with diabetes is approximately three times higher than in those without diabetes (9).

Glycemic control is important in every patient with COVID-19 because plasma glucose elevation is a risk factor for mortality and morbidity due to organ failure alone. The added effect of COVID-19 further increases the risk for organ damage in people with diabetes. It has been shown in previous studies that patients with poor glycemic control in other viral infections such as severe acute respiratory syndrome (SARS) and influenza H1N1 have an increased risk of complications and death $(10,11)$. Data on COVID-19 is limited.

Although a diabetic individual receives outpatient oral antidiabetic therapy, most of the hospitalized patients due to COVID-19, especially those with respiratory distress, switch to insulin therapy. In addition, frequent monitoring of blood glucose in these patients, especially in diabetic patients hospitalized in the intensive care unit, due to intravenous insulin infusion, and measuring blood glucose every hour or every 2 hours bring additional costs. If each blood glucose care is considered as contact with the patient, this job is also a burden for the healthcare worker. As a matter of fact, our patient, whose blood glucose was regulated at home and who used oral antidiabetic drugs, was started on insulin treatment after her hospitalization and frequent blood glucose measurements were required because her blood glucose levels were high.

Treatment with angiotensin converting enzyme (ACE) inhibitors and $\mathrm{ARB}$ has the potential to cause upregulation of ACE-2 (12). Seeing improvement in mice with lung injury treated with losartan (13) and demonstrating reduced mortality and endotracheal intubation rates in patients with viral pneumonia who continue to use ACE inhibitors (14) suggest that the use of these drugs may be beneficial. The current antihypertensive treatment was continued in our patient using ARB.

As a result, COVID-19 proved to be a more serious disease than seasonal flu in a very short time by causing a pandemic including people with diabetes. All the standard precautions taken to avoid the commonly reported infection have become even more important when dealing with this virus. If your diabetes is well managed, your risk of being seriously ill from COVID-19 is likely lower. When people with diabetes don't manage their diabetes well and experience fluctuating blood glucose, they are often at risk for a range of complications related to diabetes. Having a heart disease or other complications in addition to diabetes can worsen the chances of getting seriously ill from COVID-19, like other viral infections, as the ability to fight the infection is compromised. Blood gkucose levels may rise rapidly in patients who are hospitalized and treated, especially as a result of steroid treatments. This can cause extra burden for both the patient and the healthcare worker. It can extend the hospital stay. It is important to determine specific treatment strategies for these patients.
Informed Consent: Written informed consent was obtained from the patient for publication and accompanying images.

Conflict of Interest: None declared by the authors.

Financial Disclosure: None declared by the authors.

Acknowledgements: None declared by the authors.

\section{REFERENCES}

1. Muniyappa R, Gubbi S. COVID-19 pandemic, coronaviruses, and diabetes mellitus. Am J Physiol Endocrinol Metab. 2020;318(5):E736-41.

2. Baud D, Qi X, Nielsen-Saines K, Musso D, Pomar L, Favre G. Real estimates of mortality following COVID19 infection. Lancet Infect Dis. 2020;20(7):773.

3. Tadic M, Cuspidi C, Sala C. COVID-19 and diabetes: Is there enough evidence? J Clin Hypertens (Greenwich). 2020;22(6):943-8.

4. Guan WJ, Ni ZY, Hu Y, Liang WH, Ou CQ, He JX, et al. Clinical characteristics of coronavirus disease 2019 in China. N Engl J Med. 2020;382(18):1708-20.

5. Fadini GP, Morieri ML, Longato E, Avogaro A. Prevalence and impact of diabetes among people infected with SARS-CoV-2. J Endocrinol Invest. 2020;43(6):867-9.

6. Wang D, Hu B, Hu C, Zhu F, Liu X, Zhang J, et al. Clinical characteristics of 138 hospitalized patients with 2019 novel coronavirus-infected pneumonia in Wuhan, China. JAMA. 2020;323(11):1061-9.

7. Guo W, Li M, Dong Y, Zhou H, Zhang Z, Tian C, et al. Diabetes is a risk factor for the progression and prognosis of COVID-19. Diabetes Metab Res Rev. 2020; [Epub ahead of print]. doi: 10.1002/dmrr.3319.

8. Guan W, Ni ZY, Hu Y, Liang WH, Ou C, He JX, et al. Clinical characteristics of coronavirus disease 2019 in China. N Engl J Med. 2020;382(18):1708-20.

9. Wu Z, McGoogan JM. Characteristics of and important lessons from the coronavirus disease 2019 (COVID19) outbreak in China: Summary of a report of 72314 cases from the Chinese Center for Disease Control and Prevention. JAMA. 2020;323(13):1239-42.

10. Yang JK, Feng Y, Yuan MY, Yuan SY, Fu HJ, Wu BY, et al. Plasma glucose levels and diabetes are independent predictors for mortality and morbidity in patients with SARS. Diabet Med. 2006;23(6):623-8.

11. Badawi A, Ryoo SG. Prevalence of diabetes in the 2009 influenza A (H1N1) and the Middle East respiratory syndrome coronavirus: a systematic review and meta-analysis. J Public Health Res. 2016;5(3):733.

12. Li XC, Zhang J, Zhuo JL. The vasoprotective axes of the renin-angiotensin system: physiological relevance and therapeutic implications in cardiovascular, hypertensive and kidney diseases. Pharmacol Res. 2017;125(Pt A):21-38.

13. Yang $\mathrm{P}, \mathrm{Gu} \mathrm{H}$, Zhao Z, Wang W, Cao B, Lai C, et al. Angiotensin-converting enzyme 2 (ACE2) mediates influenza H7N9 virus-induced acute lung injury. Sci Rep. 2014;4:7027.

14. Henry C, Zaizafoun M, Stock E, Ghamande S, Arroliga $\mathrm{AC}$, White HD. Impact of angiotensin-converting enzyme inhibitors and statins on viral pneumonia. Proc (Bayl Univ Med Cent). 2018;31(4):419-23. 